\title{
INTERNATIONAL BRIEFING XXX: TRAINING AND DEVELOPMENT IN ARGENTINA
}

\section{INTRODUCTION}

The present report centers on access to Training and Development by Argentina's economy active population. The purpose of this research is to describe the continuous training system, public policies on such training, and the role of the Government in providing training opportunities. The characteristics of the training offered between 2003 and 2014 are analyzed; such characteristics show investment levels and types of training, factors that identify the main challenges Argentina must face to achieve the development of the Economy.

\section{Country Basic Data}

\section{Geography}

Argentina is located in the Southern part of the American continent. With a mainland territory of 2.791 .810 sq.km, Argentina is the second largest country in South America after Brazil, and the eighth largest in the world. The Argentine Republic shares borders with Chile to the West, Bolivia and Paraguay to the North, and Uruguay and Brazil to the East. (source: Instituto Geográfico Nacional, República Argentina).

\section{Population}

Results of the 2010 Census, published in 2012 by INDEC (Instituto Nacional de Estadísticas y Censos), reported 40,1 million inhabitants in Argentina. This population places the country thirty-second in the world raking. Of the total number of inhabitants, $46.2 \%$ lives in the province of Buenos Aires. The annual mean population growth rate for the 20012010 period is $11.4 \%$. Argentina has a life expectancy rated as medium-high, which reaches 76 years of age.

According to the above mentioned Census, the evolution of the population analysed between 1985 and 2010 shows that the aged 0 to 14 group has reached $25.5 \%$ from a previous $41.3 \%$; the group between 15 and 65 years has kept a constant of $56.6 \%$. Finally, the group comprised by over 65 years has reached $10.2 \%$ from a previous $2.1 \%$. Women represent $51.3 \%$ of the population. (INDEC, 2012)

\section{Political System}

The political system of the country is representative, republican and federal, as stated by the National Constitution. Argentina's territory is divided in 6 regions and 24 administrative divisions, i.e. 23 provinces and the autonomous city of Buenos Aires, which 
is the country capital and the site of Federal Government. The government comprises the Executive, the Legislative and the Judiciary. The Executive is headed by a President, followed by a Vice president, the next rank below the president. The Legislative comprises two Congress Chambers: that of the Representatives and that of the Senators. The Representatives last four years in office and can be reelected while the Senators last six years and can be reelected indefinitely. The Vice president heads the Senate. Finally, the Judiciary comprises the Supreme Court of Justice and the lower courts. Supreme Court and lower courts Judges remain in office for as long as their good behavior lasts.

\section{Industry and Economy}

According to 2012 World Bank official results, Argentina has a U\$S 11,452 GDP per capita. This GDP places the country among the first five per capita GDPs of the region together Chile $(15,415)$, Uruguay $(14,706)$, Brasil $(12,339)$ and Venezuela $(11,114)$.

A report by the International Monetary Bank ranks Argentina 26 among the most important economies of the world due to the country's US\$ 447,644,000 GDP. With this GDP, Argentina is the third Latin American economy after Mexico and Brazil.

Based on INDEC information, Deloitte Ltd. analyses the industrial scenario and classifies the data in different areas. In the first half of 2012, electronics and home appliances was the most active sector, with a growth in current sales, year-over-year, of $37.9 \%$ (US\$ $666,000,000$ vs. US\$ 483,000,000). In the second half, Food and Drinks exhibited a variation with a year-over-year growth of $27.6 \%$ (US\$ $6,884,000,000$ vs. US\$ $5,400,000,000)$. Next in rank are Clothing, Shoes and Linen, with a year-over-year growth of $26.9 \%$ (US\$ $286,000,000$ vs. US\$225,000,000); and Cleaning articles and Perfumes with a year-over-year growth of $25.8 \%$ (US\$1,468,000 vs. US\$1,167,000,000).

In 2012, Argentina had the 44 position worldwide according to export volume, which reached U\$D 80,927,000,000. According to the classification by the Ministry of Industry of Argentina, 23.5\% of total exported goods corresponds to Raw Material, 34\% to Farming Products, $34 \%$ to Industrial Manufactures, and, finally, $8.5 \%$ to Fuel and Energy.

The job market in Argentina comprises $19,800,000$ jobs (49.4\% of the total population), $43.5 \%$ corresponds to women positions. In 2014, unimployment reached $7.1 \%$, placing the country behind Germany (4.8\%), Brazil (5\%), and Chile (6\%); though it is ahead of France (10.3\%). Concerning level of instruction per age group, 4.7\% of Argentine working population has not completed primary school; $35.23 \%$ has completed primary education; $39.2 \%$ has finished secondary school; and, finally, $20.8 \%$ has attended the university.

(INDEC, 2014). 


\section{Education system}

The education System comprises the following levels: initial (from 45 days to five years old); primary education (age group between 6 and 12 years); secondary education (student population between 13 and 17 years of age); and higher education, which includes terciary education and the university. Figure 1 shows the structure of formal instruction in Argentina and the age of the student population in each group.

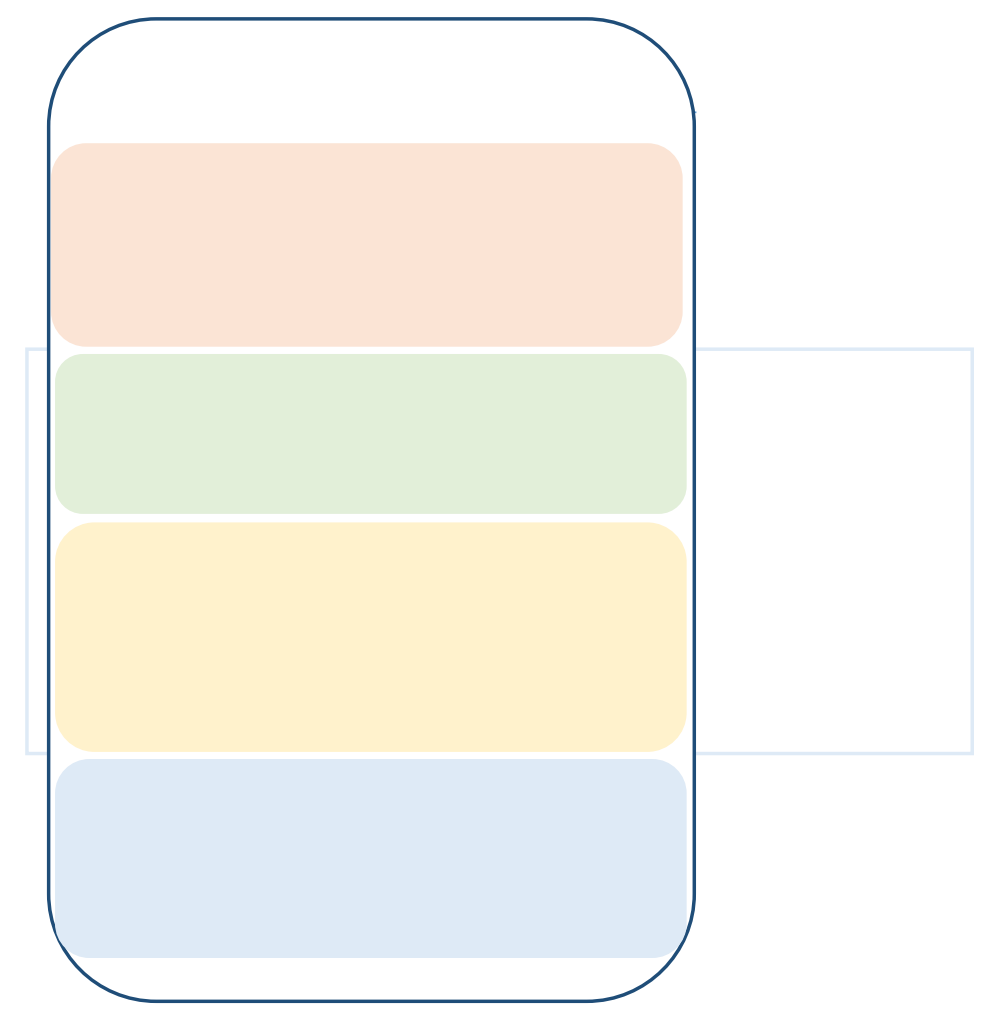

Figure 1. Structure of the Argentine educational system. Source: Argentine Ministry of Education

The Argentine system of education comprises the following areas: Special Education, Rural Education, Technical and Profesional Training, Artistic Education, Young and Adult Continuous Education, Bilingual Intercultural Education, Inmate Training Program, as well as Home and Hospital Teaching service (for sick students).

\section{Statistics in Education}

According to the National Education Law $N^{\circ} 26206$, art.3, issued in 2006, a minumun investment of $6 \%$ of GDP is guaranteed for education. Table 1 shows student enrolment per education level. The number of students in Argentina is $12,108,740$, which represent 
$30.3 \%$ of the population. Of this population, $89.1 \%$ is attending common education, $1.1 \%$ special education and $9.8 \%$ is enrolled for young and adult education.

Table 1. Number of students per 2012 survey of education level. Common Education, Special Education and Young and Adult Education.

\begin{tabular}{|c|c|c|c|c|c|}
\hline Type of education & Public & $\%$ & Private & $\%$ & Total \\
\hline Total & $8,866,480$ & 73.22 & $3,242,260$ & 26.78 & $12,108,740$ \\
\hline Common & $7,696,658$ & 63.56 & $3,098,852$ & 25.59 & $10,795,510$ \\
\hline Initial & $1,073,669$ & 8.87 & 537,176 & 4.44 & $1,610,845$ \\
\hline Primary & $3,414,473$ & 28.20 & $1,188,949$ & 9.82 & $4,603,422$ \\
\hline Secondary & $2,735,306$ & 22.59 & $1,078,239$ & 8.90 & $3,813,545$ \\
\hline Terciary & 473,210 & 3.91 & 294,488 & 2.43 & 767,698 \\
\hline Special & 103,469 & 0.85 & 28,156 & 0.23 & 131,625 \\
\hline Initial & 22,182 & 0.18 & 3,452 & 0.03 & 25,634 \\
\hline Primary & 49,245 & 0.41 & 13,789 & 0.11 & 63,034 \\
\hline Secondary & 9,698 & 0.08 & 4,008 & 0.03 & 13,706 \\
\hline Comprehensive Education Workshops & 22,344 & 0.18 & 6,907 & 0.06 & 29,251 \\
\hline Adults & $1,066,353$ & 8.81 & 115,252 & 0.95 & $1,181,605$ \\
\hline Primary & 202,485 & 1.67 & 2,216 & 0.02 & 204,701 \\
\hline Secondary & 466,757 & 3.85 & 52,383 & 0.43 & 519,140 \\
\hline Professional Training & 397,111 & 3.28 & 60,653 & 0.50 & 1. 457,764 \\
\hline
\end{tabular}

Source: 2007 to 2012 Annual Surveys. DiNIECE (Dirección Nacional de Información y Evaluación de la calidad Educativa). Argentine Ministry of Education.

\section{State Administered Training and Development Policies}

The Argentine school system is administered by the National Ministry of Education, which reports to the Executive Power in charge of ruling the education policies and strategies as The Ministry of Education comprises the Federal Council of Education, an administrative body that coordinates and brings together the education system all over the country. This council has the purpose of unifying and articulating the different manifestations of the country's Education System. The body is presided over by the National Minister of Education; it includes the maximum Education authority in each jurisdiction and three representatives of the Universities Council.

In addition, the formal Education System in Argentina is also ruled by the 26075 Education Funding Law (LFE), which was passed in December 2005 and promulgated in January 2006.

Through the Undersecretary of Education Planning, the Argentine Ministry of Education analyses the information related to characteristics, components and evolution of the National Education System expenditure as well as the evolution of teacher salaries.

Continuous training in Latin America has acquired a role in society that is growing in importance. Such statement is supported by the evolution of the laws regulating such 
formation. According to Vargas (2006), in most countries of Latin America, work training offer has increased considerably due to existing laws that guarantee the growth of those nations.

Specifically, the Continuous Training system in Argentina is designed and controlled by the Argentine Ministry of Labour, Employment and Social Security (MTEySS). The role of the Ministry is strategic and centers on promoting training conditions, as well as the assessment and acceptance of the labour skills demanded to workers by the job market in the country. In addition, this Ministry fosters the training of workers through the National Institute of Technology (INET) under a framework agreement known as National System of Continuous Training (SNFC) as a means to guaratee a proper job, and, thus, influence the country's economy.

The Ministry has implemented the "Strategic Plan of Continuous Training: Innovation and Employment, Argentina 2020", which aims at improving competitiveness and worker inclusion. The plan involves different sectors of society, such as entrepeneurs and union organizations. The main objective pursued by the Ministry is for the plan to become a tool to line up the the Continuous Training Plan with the 2020 Strategic Industrial Plan (PEI 2020). The PEI was created based on an initiative by workers, entrepenuers, universities and private and public sector agents, and coordinated by the Secretariat of Strategic Planning at the Argentine Ministry of Industry.

With this training system, the State tries to strenghten the proposed objectives by PEI 2020, which tries to upgrade the production chain in order to foster industrial development to guarantee an annual industrial GDP growth of $7 \%$.

According to Barasatian and Sladogna (2013), the "Strategic Plan of Continuous Training: Innovation and Employment, Argentina 2020" includes the following activities:

1. Professional Training Courses: Continuous Training charaterized by high technical standards and adequate for the requirements of the job market.

2. Official certification of job-specific skills developed. Recognition of workers' job experience.

3. Institutional strengthening. Quality upgrading of the Network of Continuous Training Institutions.

4. Tax Credit. Funding to companies that generate training projects and grant certification of job-specific skills developed.

5. Training for decent work. Job orientation Workshops. Aid to access to new labour rights. 


\section{Corporate Training and Development}

Barasatian and Sladogna (2013) state that the results of Continuous Training show that, in 2003, the Ministry invested US\$ 5,372,436 in training. Such training in the professional field represents $0.03 \%$ of GDP. In 2013, those figures reached US\$228,188,669, $1.3 \%$ of GDP. Table 2 shows the percetange of people trained historically.

- From 2003 to October 2014, 920,768 persons attended Professional Training courses.

The 61,374 persons that attended Professional Training courses in October 2014 did so in the following proportion:

- $36.3 \%$ under sector agreement framework.

- $40.4 \%$ under provincial agreement framework.

- $9.0 \%$ under territory agreement on employment promotion.

- $8.7 \%$ whithin the Tax Credit Program.

- $5.2 \%$ under Professional Training Programs organized by social institutions.

- $0.3 \%$ in other types of courses.

Barasatian and Sladogna (2013), claim that the professional training demand evolves into trades of greater specialization under the system of Continuous Training by MTEySS [Argentine Ministry of Labour, Employment and Social Security]. Software, Metalworking and Building are the three most salient trades.

The Software segment exhibits $100 \%$ of the training offer, characterized by qualified job training. A total of 71,500 persons were trained in two stages: the first one included 41,500 persons; the second, 30,000 workers trained in 43 computing labouratories.

The Metalworking segment is the second one in relation to the investment offered by the Ministry. By 2013, a total of 44,800 workers had been trained, and 18 professional training centers had been distributed all over the Argentine Republic. Such centers had been upgraded with latest generation equipment. In 2013, this sector grew from $76 \%$ to $84 \%$.

The Building sector was the most significant one in relation to investment, to the number of workers trained, and to the number of job-related skill certificates granted. In 2013, this sector grew from $47 \%$ to $62 \%$ in specialization trades.

These data show the shift concerning human resources professional training in Argentina. These figures show a growth of the training rates in the three segments analised, contradicting Schneider (2009), who claims that qualified hand labour is scarce in the country. 
Table 2. Continuous Training Actions. People under Professional Training according to the program. Per year. Percentages.

\begin{tabular}{|c|c|c|c|c|c|c|c|c|c|c|c|}
\hline \multirow[b]{2}{*}{ Period } & & \multirow[b]{2}{*}{$\begin{array}{l}\text { Total } \\
\text { Professional } \\
\text { formation }\end{array}$} & \multirow[b]{2}{*}{$\begin{array}{c}\text { People } \\
\text { incorporated per } \\
\text { year }\end{array}$} & \multicolumn{8}{|c|}{ Professional formation sectorial. Total (\%) } \\
\hline & & & & Sectorial & $\begin{array}{l}\text { Argentina } \\
\text { Works }\end{array}$ & Provincial & $\begin{array}{l}\text { Tax } \\
\text { Credit }\end{array}$ & Municipal & $\begin{array}{l}\text { Home } \\
\text { Provider } \\
\text { Program }\end{array}$ & $\begin{array}{l}\text { Social } \\
\text { Organizations }\end{array}$ & Other \\
\hline 2003 & & 5,406 & $0.6 \%$ & $0.0 \%$ & $0.0 \%$ & $0.0 \%$ & $0.0 \%$ & $0.0 \%$ & $100.0 \%$ & $0.0 \%$ & $0.0 \%$ \\
\hline 2004 & & 18,121 & $1.4 \%$ & $6.9 \%$ & $0.0 \%$ & $0.0 \%$ & $0.0 \%$ & $0.0 \%$ & $93.1 \%$ & $0.0 \%$ & $0.0 \%$ \\
\hline 2005 & & 33,914 & $3.0 \%$ & $47.8 \%$ & $0.0 \%$ & $16.8 \%$ & $0.0 \%$ & $0.0 \%$ & $35.4 \%$ & $0.0 \%$ & $0.0 \%$ \\
\hline 2006 & & 56,353 & $5.1 \%$ & $52.3 \%$ & $0.0 \%$ & $46.8 \%$ & $0.0 \%$ & $0.0 \%$ & $1.0 \%$ & $0.0 \%$ & $0.0 \%$ \\
\hline 2007 & & 70,302 & $6.6 \%$ & $45.1 \%$ & $0.0 \%$ & $44.9 \%$ & $0.0 \%$ & $9.7 \%$ & $0.0 \%$ & $0.0 \%$ & $0.3 \%$ \\
\hline 2008 & & 80,458 & $7.4 \%$ & $42.6 \%$ & $0.0 \%$ & $37.9 \%$ & $10.4 \%$ & $8.3 \%$ & $0.0 \%$ & $0.0 \%$ & $0.7 \%$ \\
\hline 2009 & & 123,122 & $11.0 \%$ & $35.5 \%$ & $4.0 \%$ & $42.5 \%$ & $10.8 \%$ & $6.3 \%$ & $0.0 \%$ & $0.1 \%$ & $0.7 \%$ \\
\hline 2010 & & 222,902 & $20.1 \%$ & $21.0 \%$ & $38.6 \%$ & $21.1 \%$ & $12.6 \%$ & $3.7 \%$ & $0.0 \%$ & $2.1 \%$ & $0.9 \%$ \\
\hline 2011 & & 151,848 & $12.3 \%$ & $26.5 \%$ & $12.3 \%$ & $34.7 \%$ & $15.8 \%$ & $5.9 \%$ & $0.0 \%$ & $3.0 \%$ & $1.7 \%$ \\
\hline 2012 & & 128,572 & $10.4 \%$ & $41.5 \%$ & $1.4 \%$ & $22.6 \%$ & $21.0 \%$ & $9.4 \%$ & $0.0 \%$ & $3.2 \%$ & $0.9 \%$ \\
\hline 2013 & & 138,820 & $10.8 \%$ & $37.1 \%$ & $0.1 \%$ & $20.9 \%$ & $26.5 \%$ & $10.5 \%$ & $0.0 \%$ & $4.5 \%$ & $0.4 \%$ \\
\hline 2014 & & 153,977 & $11.4 \%$ & $35.9 \%$ & $0.0 \%$ & $31.2 \%$ & $21.5 \%$ & $7.8 \%$ & $0.0 \%$ & $3.4 \%$ & $0.3 \%$ \\
\hline & Jan.-14 & 21,863 & & $10.8 \%$ & $0.0 \%$ & $38.2 \%$ & $45.6 \%$ & $3.8 \%$ & $0.0 \%$ & $0.9 \%$ & $0.7 \%$ \\
\hline & Feb.-14 & 17,725 & & $14.3 \%$ & $0.0 \%$ & $10.7 \%$ & $69.8 \%$ & $3.7 \%$ & $0.0 \%$ & $0.8 \%$ & $0.7 \%$ \\
\hline & Mar.-14 & 25,982 & & $24.4 \%$ & $0.0 \%$ & $10.2 \%$ & $57.6 \%$ & $4.9 \%$ & $0.0 \%$ & $2.3 \%$ & $0.6 \%$ \\
\hline & Apr.-14 & 38,322 & & $27.4 \%$ & $0.0 \%$ & $22.4 \%$ & $41.5 \%$ & $5.7 \%$ & $0.0 \%$ & $2.6 \%$ & $0.3 \%$ \\
\hline & May-14 & 50,266 & & $31.0 \%$ & $0.0 \%$ & $29.7 \%$ & $30.0 \%$ & $6.7 \%$ & $0.0 \%$ & $2.3 \%$ & $0.2 \%$ \\
\hline & June-14 & 52,029 & & $34.9 \%$ & $0.0 \%$ & $35.7 \%$ & $20.7 \%$ & $6.6 \%$ & $0.0 \%$ & $2.0 \%$ & $0.2 \%$ \\
\hline & July-14 & 40,828 & & $43.8 \%$ & $0.0 \%$ & $45.4 \%$ & $0.0 \%$ & $7.9 \%$ & $0.0 \%$ & $2.7 \%$ & $0.2 \%$ \\
\hline & Aug.-14 & 42,036 & & $49.9 \%$ & $0.0 \%$ & $38.0 \%$ & $0.0 \%$ & $8.5 \%$ & $0.0 \%$ & $3.4 \%$ & $0.2 \%$ \\
\hline & Sept-14 & 52,093 & & $43.5 \%$ & $0.0 \%$ & $42.5 \%$ & $0.0 \%$ & $9.4 \%$ & $0.0 \%$ & $4.3 \%$ & $0.4 \%$ \\
\hline & Oct.-14 & 61,374 & & $36.3 \%$ & $0.0 \%$ & $40.4 \%$ & $8.7 \%$ & $9.0 \%$ & $0.0 \%$ & $5.2 \%$ & $0.3 \%$ \\
\hline Historical Total & & 920,768 & & $35.4 \%$ & $11.3 \%$ & $29.2 \%$ & $11.6 \%$ & $7.0 \%$ & $2.6 \%$ & $2.2 \%$ & $0.6 \%$ \\
\hline
\end{tabular}

Source: Monthly report by the Employment Strategic Information Office. Employment Secretariat, 2014, p. 16. 
The creation of a specific legal framework in the field is one of the new challenges the Ministry must face in order to consolidate Professional Training. According to Barasatian and Sladogna (2013), at present [the Ministry] is preparing a proposal for a Law of Continuous Training.

The 2013 EIL (Job Indicator Survey) shows that, of all the companies surveyed, 59\% implemented different types of training for their personnel depending on the needs of each company. In the periods 2004/05, and 2008, the proportion of companies that provided training to their employees was $30 \%$ in $2004 / 05 ; 50 \%$ in 2008.

The survey proves that the size of the companies determines the implementation of employee training. According to the data obtained in 2013, the percentage of companies that trained their workforce was $53 \%$ for small companies, $84 \%$ for medium-sized, and $92 \%$ for large ones.

Finally, the current context offers an optimal opportunity to promote competiveness, productivity and social inclusion; in addition, it establishes that the role the Ministry is to play within the future system framework.

\section{Research on Training and Development in Argentina}

The first step to organize professional training in the country was the creation of the CONET (Technical Education National Council) in 1959. This initiative was taken with the responsibility of concentrating the national technical education, which, up to that moment, was taught by different institutions created in the decade between 1945 and 1955 such as Universidad Nacional Obrera (UNO), Comisión Nacional de Aprendizaje y Orientación Profesional (CNAOP) y la Universidad Tecnológica Nacional (UTN). The first report on the state of affairs of Professional Training was prepared by ILO to the request Argentina Government placed through CONET in 1969. The report describes the evolution of Companies' Personnel Training according to the development of the Professional Training System administered by CONET.

Another report related to training in Argentina is the one Paín (1972) prepared. This report is the result of research oriented to the analysis of workers' attitudes towards professional training in medium-sized companies.

This ILO report was followed by other two, one on Professional Training for adults in 1974, and the other on Professional Training for Industry Development and Professional Training in Company in 1976.

Experton (1994) submitted a report on university education in Argentina; the report was published by the World Bank. Ever since 2000, a number of scholars conducted a series of investigations to analize different aspects of education and training in various countries, among which Argentina was included. The World Bank published all the research reports. The 2006 reports analize the implementation of skill formation in the work force. The 
objective of this training is to contribute to the economy growth that relies on both education and professional training.

Under the auspices of the International Labour Organization and the Inter-American Centre for Knowledge Development in Vocational Training (CINTERFOR), Cappelletti et al., (2000) published their research on revaluation of professional training in the system of work relations in Argentina. This research analizes the following three mechanisms: collective bargaining, social dialogue and institutional participation instances.

Within the context of the Study Program on Youth, Education and Work (PREJET-IDES), authors such as Salvia and Tuñón (2007) have focused their research on socially excluded youth. Finally, Barasatián and Sladogna (2008) prepared a report on the role of professional training in production models.

Billorou et al., (2011), edited a guide to evaluate the impact of training by paying attention to the ILO guidelines concerning the need of counting on comparable reference parameters of investment, both in education and continuous training. In 2012, ILO prepared a report on training for work in Argentina.

Jacinto and Millenaar (2013) produced a holistic analysis of policies, institutions and structural conditions. They investigated the training mechanisms for the design of the educational-laboural stages for the working-class youth.

Gándara and Cosentino (2013) proposed the joint action of training certers, companies and unions to achieve the incorporation of young people in the job market, and, in this way, to influence the development of local economy.

Oelsner (2013) presents a historical analysis of the changes in professional training policies in Argentina during the period between 1944 and 1955. At the same time, Barasatian and Sladogna (2013) provided suggestions to strengthen the future National System of Continuous Training.

\section{Conclusion}

Argentina has a solid structure of the education system. This system comprises the following four classic education levels: Initial, Primary, Secondary, and Terciary, and eight areas of specialization, namely, Special Education, Rural Education, Technical and Profesional Training, Artistic Education, Young and Adult Continuous Education, Bilingual Intercultural Education, Inmate Training Program, as well as Home and Hospital Teaching service (for sick students). 
The Argentine Republic government invests $6 \%$ of the GDP in education. According to the data published by the Institute for Statistics of the Organization of the United Nations Educational, Scientific and Cultural Organization (UNESCO UIS), Argentina invests at the same level as as countries such as Germany (5.1\%), Brazil (5.8\%), Chile (4.2\%), France (5.9\%), Finland (6.8\%), Mexico (5\%) or USA (5.4\%). Nonetheless, according to the 2012 PISA report (OCED, 2012), Argentina exhibits a deterioration in educational quality, which places the country among the nations with lower level, just above Perú and Colombia. Such situation proves that, even though the investment is considerable, more emphasis should be put on improving students' academic performance.

In relation to the continuous training system, since mid XX century, Argentina has worked on developing a system of such training that would contribute to the upgrading of the national industry.

Ever since the first years of the XXI century, the State is facing permanent effort to improve the results of continous training. To do so, it resorts to tripartite bodies, Sector Councils, and to the development of a legal framework that would strenghthen the importance of such training.

The State engagement in the consolidation of continuous training is evident. The development of the "Strategic Plan of Continuous Training: Innovation and Employment, Argentina 2020" is one of the most tangible examples in the field, together with the creation of the corresponding specific legal framework, i.e. the design of the Continuous Training Law.

A growing tendency to training in the most specialized levels of the trades in each sector is evident; a greater incidence of training on the technologically most advanced sectors, and growth of institutionalization are evident in Argentina. Such traits could strengthen the future. In this sense, two areas have exceled others, namely, metalmechanics which grew from $76 \%$ to $84 \%$ and the building sector which grew from $47 \%$ to $62 \%$ in specialization trades.

Concerning the role played by training private companies, $59 \%$ of surveyed companies in 2013 develop their own programs. That year report shows that, in most companies, training is directly related to the size of the company. Results show that $92 \%$ of big companies has continuous training programs, while only $53 \%$ of small enterprises has such programs.

Another important aspect to examine is the Continuous Training Law. Such regulation should consider different aspects of the functions and missions of the future system, the creation of a governing body and its place in the State system in relation to both social sectors and the State, as well as the definition of specific roles. 
In spite of investing on education at the level of developed countries, Argentina has not achieved optimal results due to the short time period of implementation of increased education funding. The country raised the investment percentage in education not long ago, 2009; such policy would account for the position the country has, worldwide with respect to GDP investment in eduction, according to the results of the PISA report. The main challenge of the country would be to upgrade the results in education to reach the first positions in the world.

Concerning Continous Training, Argentina has exhibited steady activity since mid XX century. Such activity has fostered a solid system, in which the State is the main administrator.

\section{Sources of information on Training and Development}

Public Administration

- Instituto Nacional de Estadística y Censos (http://www.indec.mecon.ar) (Consultado 18 agosto 2014)

- Consejo Federal de Educación (http://portal.educacion.gov.ar/consejo/) (Consultado 7 julio 2014)

- Ministerio de Educación de la Presidencia de la Nación (http://www.educacion.gov.ar) (Consultado 8 enero 2015)

- Ministerio de Trabajo, Empleo y Seguridad Social (http://www.trabajo.gob.ar) (Consultado 7 octubre 2014)

- Ministerio de Industria (http://www.industria.gob.ar/) (Consultado 3 octubre 2014)

Institutions

- Banco Mundial (http://www.bancomundial.org)

- Empleartec (http://www.empleartec.org.ar) (Consultdo 17 septiembre 2014)

- Fondo Monetario Internacional (http://www.imf.org) (Consultado 16de octubre 2014)

- Organización de Estados Americanos (http://www.ibe.unesco.org/en/services/onlinematerials/publications.html) (Consultado 25 de septiembre 2014)

- Instituto Geográfico Nacional, República Argentina:

(http://www.ign.gob.ar/NuestrasActividades/Geografia/DatosArgentina)

(Consultado 20 de agosto 2014)

Laws and Regulations

- Ley de Educación Nacional 26.206

- Ley de Financiamiento Educativo26.075

- Ley de Educación Técnico Profesional № 26.058 
- Resolución C.F.E. no 167/12 anexo 1. Plan Nacional de Formación Docente 2012/2015

- Resolución C.F.E: no 201/13. Programa Nacional de Formación Permanente

\section{Training Sector Companies}

\section{Deloitte}

Deloitte:https://www.deloitte.com/view/es_AR/ar/ideasperspectivas/publicaciones/4922df3c4f25a410VgnVCM3000003456f70aRCRD.htm (Consultado 10 de marzo de 2014).

\section{Bibliography}

Banco Mundial. Informe sobre el desarrollo mundial 2006. Equidad y desarrollo. Washington D.C.

Barasatián, S. y Sladogna, M. (2008), El desafío de la Formación Continua. Andamios, Buenos Aires 1, 1, 4-7.

Barasatian, S. y Sladogna, M. (2013), Dialogo Social Institucionalizado en la Formación Profesional, Organización Internacional del Trabajo.

Billorou, N., Pacheco, M. y Vargas, F. (2011), Guía para la Evaluación de Impacto de la Formación. CINTERFOR, International Labour Office, Cinterfor/OIT, Occupational Training.

Cappelletti, B., Schütz, J., Soto, C. y Herrera, M. (2000), Actores Sociales y Formación en Argentina. (Montevideo: OIT - CINTERFOR).

Experton, W. (1994), Higher education: The lessons from experience, comments from around the world on the World Bank's higher education paper. Higher Education in Argentina, NORRAG News, 39-41.

Gándara, G. y Cosentino, R. (2013), 'El rol de los Centros de Formación Profesional en Relación al Sostenimiento del modelo de desarrollo con inclusión social'. Ponencia realizada en el congreso USACH internacional del conocimiento, Chile. Available at: http://www.fundacion.uocra.org/documentos/recursos/articulos/el-rol-de-los-centrosde-formacion-profesional.pdf. (Consultado 10 de noviembre 2014)

INDEC (2012), Censo Nacional de Población, Hogares y Viviendas 2010. (Buenos Aires, Instituto nacional de estadística y censos). Available at: http://www.estadistica.sanluis.gov.ar/estadisticaWeb/Contenido/Pagina148/File/LIBRO/c enso2010 tomo1.pdf (Consultado 31 de enero 2015). 
INET (2002), Acuerdo Marco. Sistema Nacional de Formación Profesional de la República Argentina. Disponible en http://www.me.gov.ar/consejo/resoluciones/res02/193-02ane1.pdf. (Consultado 30 de enero de 2015).

Jacinto, C. y Millenaar, V. (2013), 'Educación, capacitación y transiciones laborales. ¿Rupturas provisorias en las trayectorias de los jóvenes provenientes de hogares de bajo capital educativo?', Sudamérica 2, 63-90.

Ministerio de la Producción, Ciencia y Tecnología. Plan Estratégico industrial 2020, 1-59. Available at. http://www.industria.gob.ar/plan-estrategico-2020/. (Consultado 12 de diciembre de 2014).

Ministerio de Trabajo, Empleo y Seguridad Social. Encuesta de Indicadores Laborales (EIL) (2013), Actividades de Capacitación en Empresas Privadas. Subsecretaría de Programación Técnica y Estudios Laborales. Dirección General de Estudios y Estadísticas Laborales.

Ministerio de Trabajo, Empleo y Seguridad Social. Informe Mensual de la Dirección de información Estratégica para el Empleo (2014). Secretaría de Empleo, 16.

Ministerio de Trabajo, Empleo y Seguridad Social. Plan Estratégico de Formación Continua: Innovación y Empleo. Argentina 2020. Available at: http://www.trabajo.gov.ar/downloads/formacioncontinua/planestrategico2020.pdf.

Oelsner, V. (2013), 'Forging the Fatherland": Work and vocational education in Argentina during Peronism (1944-1955)', Pedagógica Histórica, 49, 3, 382-401.

Organización de Estados Americanos (OEA) (2011), Datos Mundiales de Educación $2010 / 2011$.

Organización Internacional del Trabajo (OIT) (1959), Informe Provisional al Gobierno de la República Argentina sobre la Formación Profesional de Mano de Obra Calificada para la Industria.

Organización Internacional del Trabajo (OIT) (1969), Análisis de Formación Profesional en Empresas.

Organización Internacional del Trabajo (OIT) (1974), Informe sobre la Formación Profesional para el Desarrollo Industrial Argentina. Formación Profesional de Adultos.

Organización Internacional del Trabajo (OIT) (1976), Informe sobre la Formación Profesional para el Desarrollo Industrial Argentina. Formación Profesional en la Empresa.

Organización Internacional del Trabajo (OIT) (2012), La formación para el trabajo en Argentina. 
Paín, A. (1972), Actitudes de los trabajadores ante la Formación Profesional: una Encuesta en Buenos Aires. CINTERFOR. Centro interamericano de investigación y Documentación sobre Formación Profesional.

Palomino, H. y Dalle, P. (2012), 'El impacto de los cambios ocupacionales en la estructura social de la Argentina: 2003-2011'. Revista de trabajo 8,10, 205-223.

Salvia, A. y Tuñón, I. (2007), 'Jóvenes excluidos: límites y alcances de las políticas públicas de inclusión social a través de la capacitación laboural'. Revista de Estudios Regionales y Mercado de Trabajo, 3, 51-67.

Schneider, B. (2009), 'Hierarchical Market Economies and Varieties of Capitalism in Latin America'. Journal of Latin American Studies, 41, 03, 553-575.

UNESCO International Institute for Educational Planning (2014), Informe sobre tendencias sociales y educativas en América Latina 2014. Políticas TIC en los Sistemas Educativos de América Latina.

Vargas, F. (2006), 'Competencias en la Formación y en la Gestión del Talento Humano. Anales de la educación común', Tercer siglo, 2, 5. Publicación de la Dirección General de Cultura y Educación de la Provincia de Buenos Aires, Dirección Provincial de Planeamiento. 